\title{
HER2/Neu Positive by Immunohistochemistry 81-90 Percent
}

National Cancer Institute

\section{Source}

National Cancer Institute. HER2/Neu Positive by Immunohistochemistry 81-90 Percent. NCI Thesaurus. Code C141502.

An immunohistochemical staining finding indicating that 81-90 percent of the cells in a tissue sample are expressing receptor tyrosine-protein kinase erbB-2. 